\title{
Tempat Sampah Pintar Berbasis Internet of Things (IoT) Dengan Sistem Teknologi Informasi.
}

\author{
Mualief Anwar Ismail \\ Prodi Teknik Elektro \\ Universitas Ichsan Gorontalo \\ Gorontalo, Indonesia \\ Sandyismai105@gmail.com
}

\author{
Riska K. Abdullah \\ Prodi Teknik Elektro \\ Universitas Ichsan Gorontalo \\ Gorontalo, Indonesia \\ alternative.xen@gmail.com
}

\author{
Syahrir Abdussamad \\ Prodi Teknik Elektro \\ Universitas Negeri Gorontalo \\ Gorontalo, Indonesia \\ syahrirabdussamad@ung.ac.id
}

\begin{tabular}{ll}
\hline Diterima & : November 2020 \\
Disetujui & : Desember 2020 \\
Dipublikasi & : Januari 2021 \\
\hline
\end{tabular}

Abstrak-Mengangkat dari permasalahan sampah yang berserakan di sekitar area tong sampah, permasalahan tersebut kini dapat di tangani dengan sebuah penelitian tentang tempat sampah pintar. Metode yang digunakan adalah eksperimen dan perancangan dimana pengujian dilakukan terhadap jarak sensor, ketinggian sampah dan respon data terhadap web server. Tempat sampah ini menggunakan teknologi raspberry pi dan internet of things (IoT) yang bersifat berbasis website. Sistem akan dibuat dari rangkaian pendukung yaitu, sensor HC-SR04 sebagai pendeteksi objek dan data sampah. Sementara itu, pada output di gunakan motor servo sebagai penggerak penutup tong sampah, selain itu terdapat Web server sebagai pengecekan data sampah dari jarak jauh. Pada bagian selanjutnya terdapat pula output berupa LED sebagai pemberi tahu keadaan tong sampah ketika penuh atau kosong secara langsung. Hal ini dapat membantu tingkat kesadaran masyarakat dalam hal membuang sampah tidak pada tempatnya. Hasil yang diperoleh dalam penelitian ini adalah buka tutup tong sampah dengan setingan perangkat lunak lebih kecil dari $60 \mathrm{~cm}$ terbuka dan lebih besar dari $60 \mathrm{~cm}$ tidak terbuka. Selanjutnya hasil pendeteksia sensor terhadap level sampah $8 \mathrm{~cm}$ level penuh, 21-28 cm level setengah dan $48 \mathrm{~cm}$ level kosong. Dan hasil pengiriman data ke web server semua level sampah terdeteksi sudah sesuai.

Kata kunci: Raspberry Pi, sensor, Internet of things (IoT), Web server, motor servo.

Abstract - Taking the problem of garbage scattered around the trash can area, this problem can now be handled with a study on smart trash cans. The method used is experimental and design where testing is carried out on sensor distance, waste height and data response to the web server. This trash can uses raspberry pi technology and internet of things (IoT) which is website-based. The system will be made from a series of supports, namely the HC-SR04 sensor as object detection and garbage data. Meanwhile, at the output, a servo motor is used to drive the trash can cover, besides that there is a Web server for checking waste data remotely. In the next section there is also an output in the form of an LED as a direct notification of the state of the trash can when it is full or empty. This can help the level of public awareness in terms of disposing of waste inappropriately. The results obtained in this study are open and close trash cans with software settings smaller than $60 \mathrm{~cm}$ open and larger than $60 \mathrm{~cm}$ not open. Furthermore, the sensor detection results for the waste level of $8 \mathrm{~cm}$ full level, $21-28 \mathrm{~cm}$ half level and $48 \mathrm{~cm}$ empty level. And the results of sending data to the web server, all levels of waste detected are appropriate.

Keywords: Raspberry Pi, sensor, Internet of things (IoT), Web server, servo motor.

\section{Pendahuluan}

Sampah merupakan salah satu dampak negatif dalam lingkungan kemasyarakatan, maupun lingkungan terpencil atau perkampungan. Meskipun pihak pemerintah dan badan lingkungan hidup (BLH), menyediakan tempat sampah tetapi kesadaran masyarakat dalam membuang sampah tidaklah pada tempatnya. Biasanya yang sering terjadi jika tempat sampah penuh maka masyarakat akan membuang sampah di sekitar area tempat sampah, hal ini mengakibatkan pencemaran lingkungan dan menimbulkan bau-bau yang tidak nyaman dalam satu lingkungan hidup.

Teknologi yang berkembang sekarang ini yang memanfaatkan piranti-piranti digital sehingga dapat membantu dalam mengerjakan hal-hal yang rumit sekaligus. Pemanfaatan teknologi ini misalnya dalam mengatur buka tutup tempat sampah, pengenalan terhadap objek yang mengunakan sensor dan dikontrol melalui mikrokontroler.

Dari permasalahan membuang sampah penulis dapat mengembangkan tempat sampah, yang bisa membantu masyarakat dalam hal tidak membuang sampah pada area sekitar tong sampah. Hal ini dapat membuat penulis berpikir, bahwa jika tempat sampah di buat lebih efektif dalam membantu masyarakat membuang sampah. Alangkah baiknya masyarakat atau warga setempat, mengetahui terlebih dahulu kondisi tempat sampah. Kosong atau penuh dari jarak jauh atau dari rumah warga setempat, agar masyarakat tidak lagi membuang sampah di area sekitar tong sampah.

Tujuan dari penelitian ini adalah bagaimana masyarakat setempat bisa mengetahui kondisi sampah, yang penuh atau kosong dari jarak jauh melalui sistem monitoring menggunakan web server serta bagaimana mengaplikasikan tempat sampah untuk buka dan tutup pintu otomatis 
menggunakan sensor HC-SR04, saat masyarakat ingin membuang sampah.

\section{KAJIAN PUSTAKA}

Melakukan suatu penelitian perencanaan sistem tempat sampah pintar dengan sensor HC-SR04 berbasis arduino uno $r 3$, yang di angkat dari permasalahan pengurusan sampah yang tidak baik dapat mengakibatkan lingkungan yang tidak sehat. Penggunaan mikrokontroler banyak digunakan diantaranya dalam penelitian penetuan lokasi UMKM [1], jasa percetakan [2], peringatan dini [3] . Dalam penelitiannya sensor yang digunakan adalah sensor HC-SR04 yang berfungsi sebagai pendeteksi objek atau manusia yang ingin membuang sampah dengan jarak kurang dari $10 \mathrm{~cm}$ dan otomatis servo akan membuka penutup pintu tempat sampah. Dan jika tempat sampah sudah pada titik penuh maka sirene akan berbunyi secara otomatis. Banyak permasalahan tentang sampah diantaranya [4], [5], [6], [7], mereka mengangkat tema tentang sampah yang dapat dimonitoring dengan mengguna smart phone hal in sangat membantu instansi maupun perorangan untuk dapat menginfomasikan tong sampah masih kosong maupun tong sampah yang sudah penuh.

\section{METODE PENELITIAN}

Metode yang digunakan dalam artikel ini adalah metode experimen sejalan dengan [8] dan dan metode perancangan [9], pemilihan metode yang diambil adalah karena melakukan perncanga dan selanjutnya melakukan beberapa pengujian (eksperimen) untuk mendapatkan hasil yang diinginkan. Disamping itu Web server dibuat dengan menggunakan aplikasi thingspeak. Thingspeak ini adalah sebuah Web server yang sudah jadi dan sudah menyediakan chenel untuk pengelolaan data informasi yang masuk dan keluar, serta untuk mempublis data. Pengguna hanya butuh mencari ID chanel untuk mengakses informasi datanya.

\section{A. Sumber Data}

Dari penelitian ini sumber data yang di dapat yakni dari, bacaan-bacaan jurnal sebelumnya yang membahas tentang tempat sampah pintar yang menggunakan microcontroller, dan internet of things (IOT), dan juga mengamati referensi cara penanggulang sampah secara otomatis, dari jurnaljurnal sebelumnya.

\section{B. Metode Pengumpulan Data}

Dari penelitian ini penulis memakai metode-metode penelitian observasi dan pendalaman bibliografi yakni:

1. Observasi

Observasi yang dimaksud yaitu, terang-terangan dan mengamati kondisi tempat sampah yang ada di beberapa wilayah kota Gorontalo, dan bagaimana cara penanganannya terhadap sampah yang berserakan.

2. Pendalaman bibliografi

Cara pengumpulan data yaitu mengumpulkan bibliografi, referensi jurnal dan metode-metode yang berkaitan dengan artikel ini.

\section{Sarana Penelitian}

Sarana yang di pakai pada proses tugas akhir ini yakni:

1. Perangkat keras

Dari perangkat keras yang di gunakan pada pengembangan tugas akhir ini, dalam bentuk data ataupun teori-teori dasar yaitu:

a. Laptop Acer windows 10 dengan spesifikasi

1) Processor inter® cort $^{\mathrm{tm}} \mathrm{i} 3-5005 \mathrm{u} \mathrm{cpu}$

2) $\operatorname{Ram} 2$ GB

3) 64-bit operating sistem

b. Hand phone mi 8 lite dengan spesifikasi

1) Versi MIUI 10 global 9.6 .27 beta

2) Ram 4,00gb/ Internal 64,00gb

2. Perangkat lunak

Dari perangkat lunak yang di pakai pada tugas akhir ini yaitu:

1) Google chrome

2) Sistem operasi windows 10 ultimate 64-bit

3) Web server

4) Driver android

\section{Perancangan Sistem}

Guna memperjelas pembuatan sistem yang dibuat untuk tempat sampah pintar menggunakan raspberry pi dan internet of things (IoT), dengan keluaran Berupa sistem pengelolaan tempat sampah, penulis menggambarkan blok diagram dengan prinsip kerja secara umum pada Gambar 1.

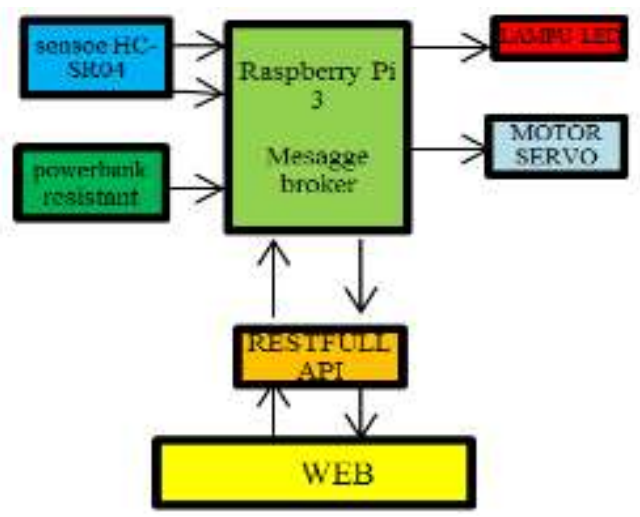

Gambar 1. Diagram blok sistem tempat sampah pintar

Dari perancangan ini dapat di jelaskan secara umum tiaptiap blok, yang berfungsi sebagai berikut:

a) Raspberry $P i$, yaitu sebagai microcontroller dan pengelola data dari alat tersebut sejalan dengan [10].

b) Message broker (MQTT), message broker berfungsi sebagai pengatur pengiriman data. yang dimaksud pengatur yaitu, message broker bisa menyimpan data yang tidak terkirim disebabkan oleh jaringan tidak stabil, dan bila jaringan sudah stabil message broker dapat mengirim data kembali secara utuh.

c) Restful API, merupakan suatu teknologi sebagai jembatan komunikasi antara mesin dengan mesin. desain kontak 
Web, secara terbuka melebihkan HTTP (Hypertext transfer protokol) untuk kontak perangkat.

d) Web server, merupakan perangkat lunak yang berfungsi untuk menerima permintaan berupa halaman Web, melalui protokol HTTP atau HTTPS atau yang di kenal browser. Web server juga dapat mengirim kembali atau merespon kembali hasil dari permintaan.

e) Sensor HC-SR04 sejalan dengan penelitian [11], dari gambar diagram blok sensor HC-SR04 dapat dilihat ada 2 buah sensor dikarenakan fungsi dari setiap sensor berbeda, tetapi prinsip kerjanya sama, sama-sama mendeteksi objek melalui gelombang ultrasonik atau bisa di bilang sensor yang mendeteksi jarak. Sensor 1 mendeteksi benda atau objek lainnya yang ada di depan tong sampah, dan sensor 2 mendeteksi keadaan tong sampah penuh atau kosong (level sampah).

f) Power bank resistant, atau power bank yang menggunakan panel surya, power bank ini berfungsi sebagai sumber energi listrik.

g) Motor servo, di sini merupakan penggerak pintu tong sampah, jika ada objek yang terdeteksi oleh sensor jarak maka dengan otomatis servo akan membuka penutup pintu tempat sampah.

h) Lampu LED, merupakan output dari progres sensor pendeteksi data sampah, lampu ini menandakan sebuah keadaan tong sampah penuh atau kosong.

\section{HASIL DAN PEMBAHASAN}

\section{A. Tahapan Alur Penelitian}

Dari tahapan alur penelitian ini, ada beberapa konsep atau kerangka. Yang mencerminkan isi metode penelitian, atau menampilkan alur cerita seperti pada Gambar 2.

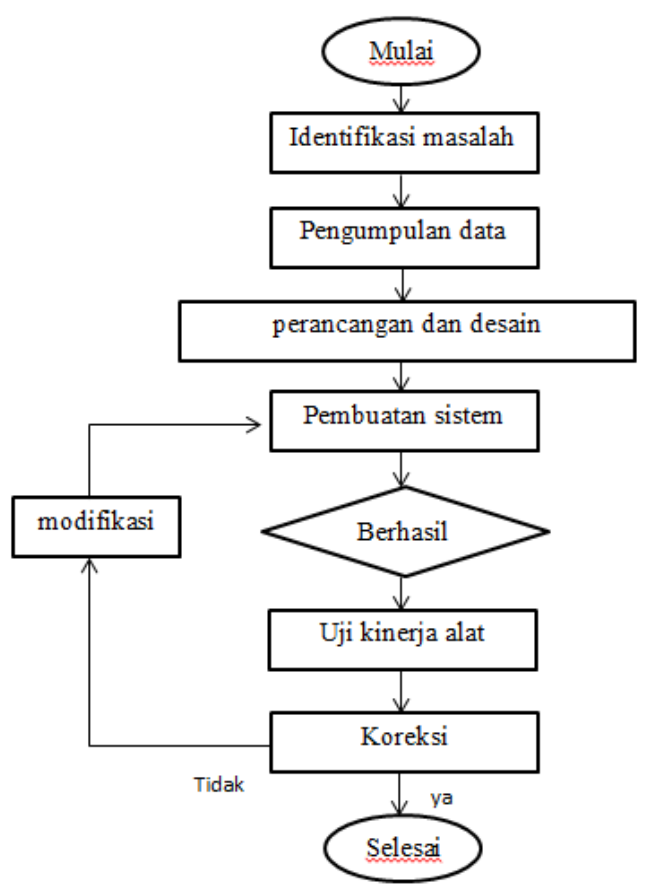

Gambar 2. Diagram tahapan alur penelitian
Proses penjabaran tahapan alur penelitian ini dapat di jelaskan secara singkat yakni:

1. Mulai atau awal dari penelitian ini yaitu, memikirkan judul penelitian yang akan diteliti.

2. Identifikasi masalah merupakan analisa permasalahan yang di dapat dari penelitian yang di lakukan.

3. Pengumpulan data yaitu peneliti mengumpulkan data berupa observasi dan pendalaman bibliografi, agar permasalahan yang di angkat bisa ditangani dengan usulan sistem yang dapat menangani permasalahan yang di angkat.

4. Perancangan dan desain yaitu bagaimana peneliti merancang satu sistem sekaligus dengan desain pada sistem yang di usulkan.

5. Pembuatan sistem merupakan pembuatan atau penciptaan satu sistem tempat sampah pintar.

6. Uji kinerja alat yaitu, alat atau sistem yang di buat akan di uji kegunaannya. bila sesuai, alat atau sistem dikatakan berhasil.

7. Koreksi yaitu bila ada kesalahan sistem atau gagal akan di modifikasi atau di perbaiki kembali.

8. Modifikasi yaitu satu sistem yang bermasalah akan di di perbaiki kembali sesuai dengan kinerja yang di inginkan.

9. Selesai atau berhasilnya sistem tempat sampah pintar yang menggunakan microkontroler raspberry pi4 dengan teknologi sistem informasi.

\section{B. Rangkaian Seluruh Sistem}

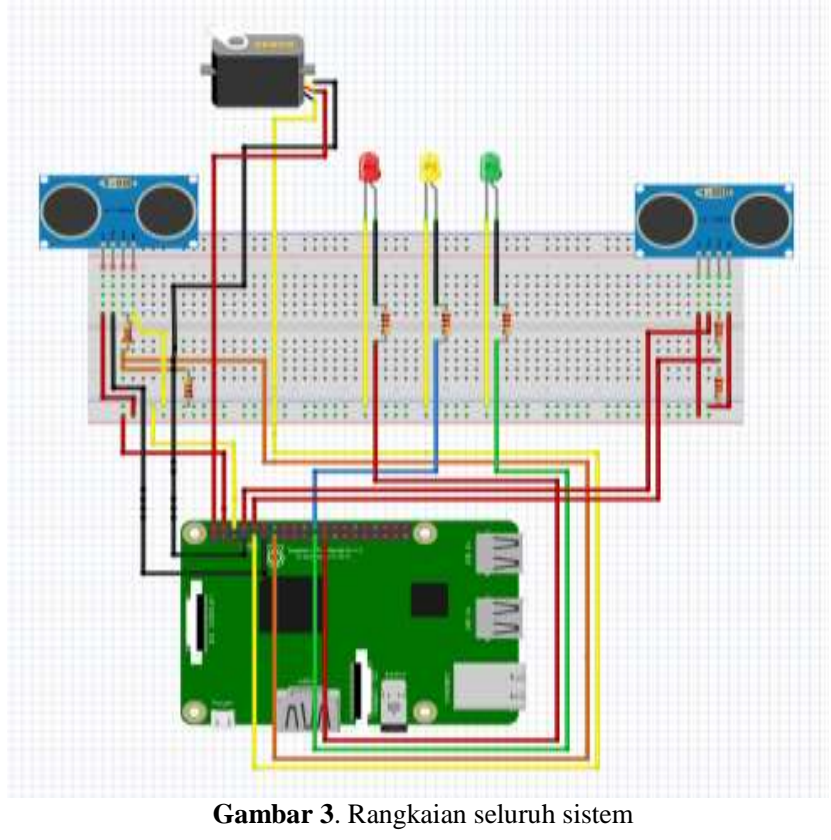

Pada Gambar 3. dapat di jelaskan hubungan seluruh rangkaian, Sistem kerja rangkaian ini saling terkait. Maksud dari saling terkait yaitu, bila sensor HC-SR04 1 pendeteksi objek bekerja. Maka sensor HC-SR04 2 pendeteksi level sampah akan mati, atau dapat dikatakan bila sensor HCSR04 1 pendeteksi objek memerintah motor servo untuk membuka pintu tong sampah. Maka sensor HC-SR04 2 pendeteksi level sampah akan mati sejenak, dan tidak dapat menghitung ketinggian sampah sementara. Hal ini juga 
berpengaruh pada lampu indikator, lampu indikator tidak dapat berpindah - pindah. Jika motor servo masih membuka pintu tempat sampah, dan setelah motor servo menutup pintu tempat sampah. Maka sensor HC-SR04 2 pendeteksi level sampah akan bekerja, dan otomatis akan memerintah lampu indikator berpindah. Jika ketinggian level berubah sesuai yang di tetapkan pada skrip pemograman.

\section{Rangkaian Ultrasonik Dan Servo}

Gambar 4 merupakan rangkaian HC-SR04 1 dan motor servo serta tabel I untuk penggunaan pin-pin GPIO untuk sensor ultrasonik dan motor servo.

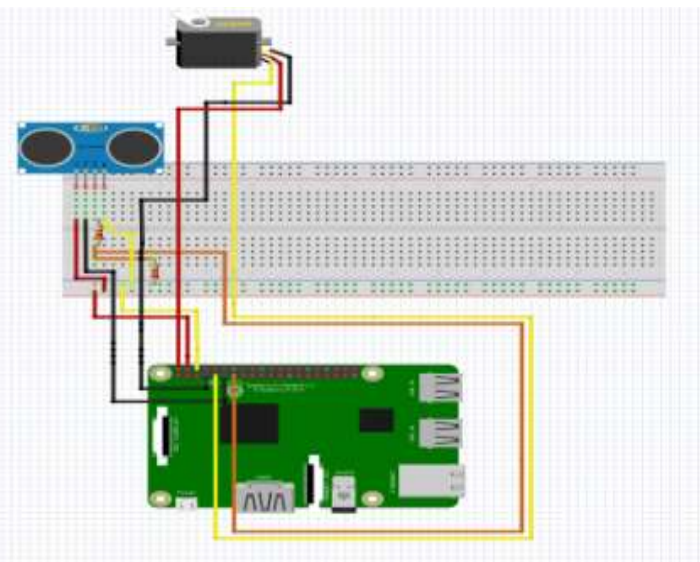

Gambar 4. Rangkaian ultrasonik dan motor servo

\begin{tabular}{|l|l|l|}
\multicolumn{4}{c}{ Tabel I. Pin GPIO alat hadware } \\
\hline HADWARE & TERMINAL & PIN GPIO \\
\hline \multirow{4}{*}{ Sensor ultrasonik 1 } & Vcc & GPIO 4 \\
\cline { 2 - 3 } & Triger & GPIO 11 \\
\cline { 2 - 3 } & Echo & GPIO 13 \\
\cline { 2 - 3 } & Grond & GPIO 6 \\
\hline \multirow{4}{*}{ Motor servo } & Echo & GPIO 7 \\
\cline { 2 - 3 } & Vcc & GPIO 2 \\
\cline { 2 - 3 } & Grond & GPIO 9 \\
\hline
\end{tabular}

\section{Rangkaian Ultrasonik Dan Lampu LED}

Rangkaian sensor HC-SR04 2 dan lampu LED diperlihatkan pada Gambar 5 serta tabel II untuk penggunaan pin-pin GPIO untuk sensor ultrasonik dan lampu LED.

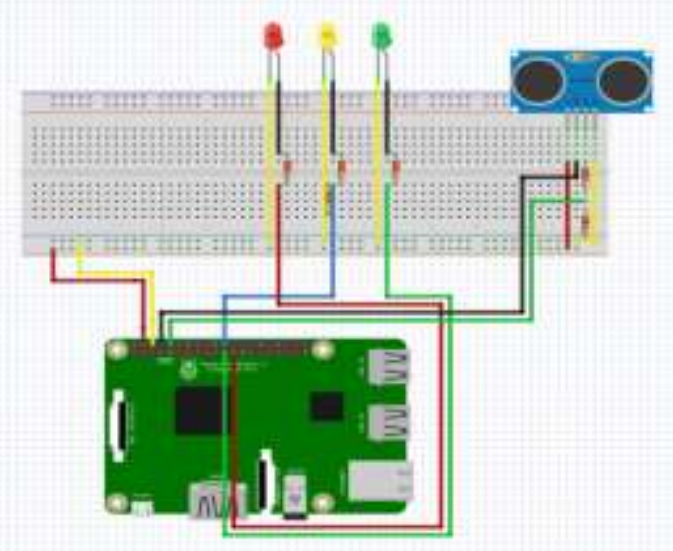

Gambar 5. Rangkaian ultrasonik dan lampu LED
Tabel II. Pin GPIO alat hadware

\begin{tabular}{|l|l|l|}
\hline Hadware & Terminal & Pin GPIO \\
\hline \multirow{3}{*}{ Sensor ultrasonik 2 } & Vcc & GPIO 4 \\
\cline { 2 - 3 } & Triger & GPIO 8 \\
\cline { 2 - 3 } & Echo & GPIO 10 \\
\cline { 2 - 3 } & grond & GPIO 6 \\
\hline Led merah & vcc & GPIO 23 \\
\hline Led kuning & vcc & GPIO 22 \\
\hline Led hijau & vcc & GPIO 21 \\
\hline & & GPIO 6 \\
\hline
\end{tabular}

Bentuk dari perancangan perangkat keras secara keseluruhan, dari sistem tempat sampah pintar menggunakan Rasbeprry pi4 dengan sistem teknologi informasi.

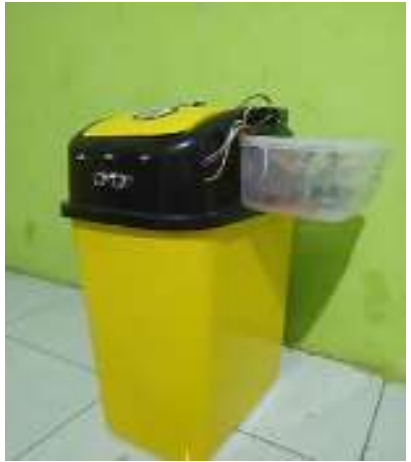

Gambar 6. Bentuk fisik keseluruhan tempat sampah pintar

Dari Gambar 6 terlihat bentuk fisik dari tempat sampah pintar, tempat sampah pintar ini terdiri dari beberapa perangkat keras yaitu.

- 1 Buah tong sampah

- 1 Buah kotak alat

- 1 Buah microcontroller Rasbeprry pi 4

- 2 Sensor ultrasonik

- 3 Buah lampu LED

- 7 buah resistor

- 1 Buah motor servo

- 1 Buah papan PCB

Seluruh rangkaian perangkat keras ini di hubungkan dengan kabel jumper, dengan cara di solder di papan PCB.

\section{E. Hasil Perancangan Perangkat Lunak}

Hasil dari perancangan Web server dapat dilihat pada screenshot interface Gambar 7. Kita dapat melihat tampilan yang berisi deskripsi tempat sampah beserta ID saluran atau chanel, dan juga akses pribadi maupun publik.

Web server di sini dibuat dengan menggunakan aplikasi thingspeak. Thingspeak ini sebuah Web server yang sudah jadi dan sudah menyediakan chenel untuk pengelolaan data informasi yang masuk dan keluar, serta untuk mempublis data. Pengguna hanya butuh mencari ID chanel untuk mengakses informasi datanya. 


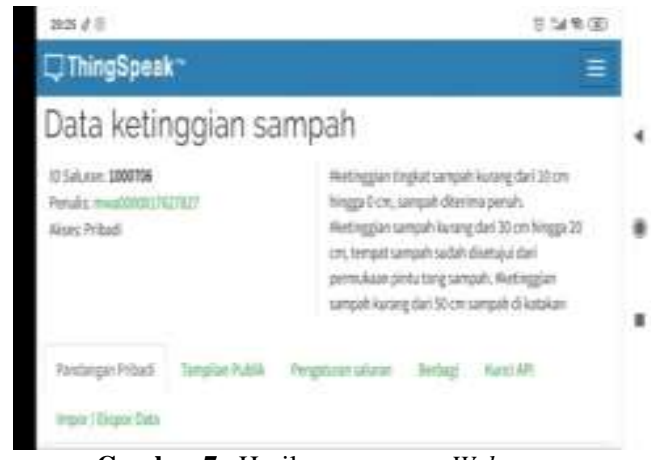

Gambar 7. Hasil perancangan Web server

\section{F. Hasil Pengujian Secara Keseluruhan}

Pengujian secara keseluruhan, dimulai dari aktifnya rasberry pi4 model B. Fungsi dari perangkat ini untuk mengontrol seluruh rangkaian yang terpasang pada pin-pin GPIO raspberry pi4. Hasil dari pengujian ini dimulai dari sensor ultrasonik 1 sebagai pendeteksi objek atau benda padat, sensor ini dapat mendeteksi pergerakan yang mendekat. Aksi yang terjadi ketika ada objek yang mendekat, maka ultrasonik 1 akan memerintah motor servo membuka pintu tong sampah seperti pada Gambar 8. Disini motor servo yang digunakan yaitu metal gear MG996R dengan kekuatan muatan 1 kilo untuk skala laboratorium, jika digunakan pada tempat umum harus menggunakan yang lebih besar kekuatan muatannya sesuai dengan beban muatan motor servo.

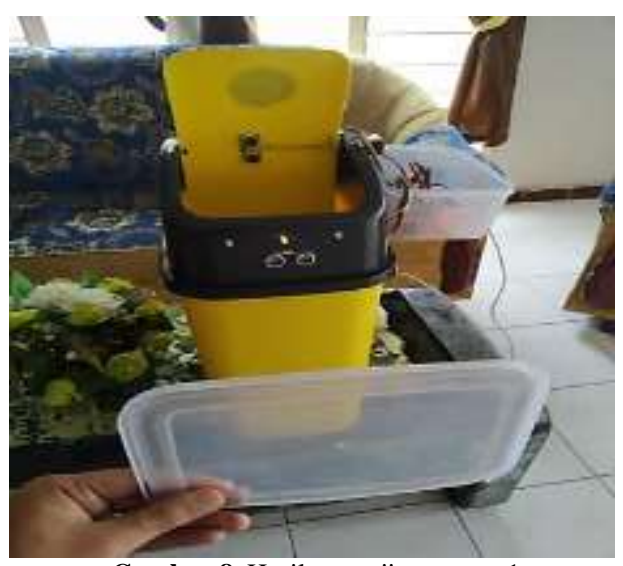

Gambar 8. Hasil pengujian sensor 1

Web server merupakan output dari alat tempat sampah pintar ini, atau dapat di jelaskan bahwa Web server di sini untuk menampilkan hasil data dari perhitungan sensor level sampah. Hasil tampilan data dari Web server ini berbentuk garis, yang datanya di update setiap 10 menit seperti pada Gambar 9 .

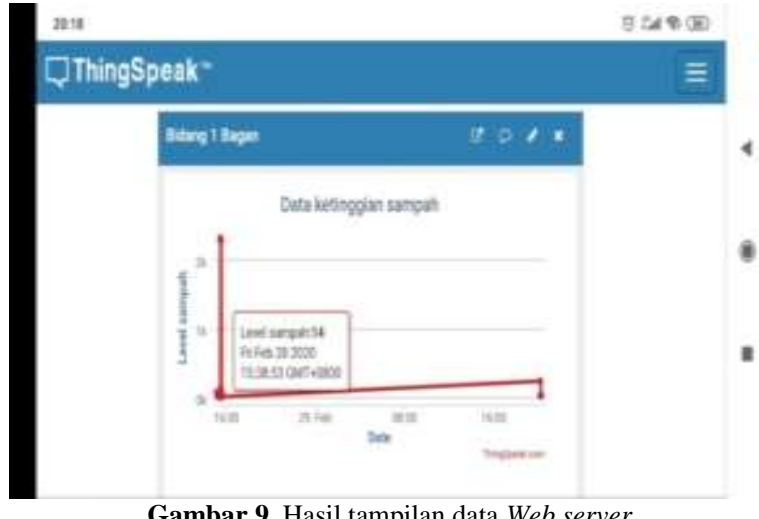

Gambar 9. Hasil tampilan data Web server

\section{G. Pengujian Sensor Ultrasonik 1}

Seperti yang terlihat pada tabel 3 adalah pengujian sensor ultrasonik 1. Untuk mengetahui jarak yang di tentukan dengan jarak perhitungan keluaran dari sensor.

Tabel 3. Pengujian sensor pendeteksi buka tutup tong sampah

\begin{tabular}{|l|c|c|c|}
\hline \multirow{4}{*}{ No } & \multicolumn{2}{|c|}{$\begin{array}{c}\text { Pengujian sensor } \\
\text { pendeteksi buka tutup tong } \\
\text { sampah }\end{array}$} & \multirow{2}{*}{ Keterangan } \\
\cline { 2 - 3 } & $\begin{array}{c}\text { Jarak } \\
\text { yang di } \\
\text { tentukan }\end{array}$ & $\begin{array}{c}\text { Hasil } \\
\text { perhitungan } \\
\text { sensor }\end{array}$ & \\
\hline 1. & \multirow{2}{*}{$60 \mathrm{~cm}$} & $45 \mathrm{~cm}$ & Terbuka \\
2. & $60 \mathrm{~cm}$ & Terbuka \\
3. & & $70 \mathrm{~cm}$ & Tidak terbuka \\
& & &
\end{tabular}

Dapat dilihat bahwa, jarak yang di tentukan peneliti adalah $60 \mathrm{~cm}$. Bila objek yang di deteksi sensor di atas dari angka $60 \mathrm{~cm}$, maka sensor tidak akan melakukan perintah ke motor servo.

\section{H. Pengujian Sensor Ultrasonik 2}

Pada tabel 4 pengujian sensor ultrasonik 2 digunakan untuk mengetahui jarak yang di tentukan dengan jarak perhitungan keluaran dari sensor.

\begin{tabular}{|c|c|c|c|}
\hline \multirow{2}{*}{ No } & \multicolumn{2}{|c|}{ Pengujian sensor pendeteksi level sampah } & \multirow[b]{2}{*}{ Keterangan } \\
\hline & $\begin{array}{l}\text { Jarak yang di } \\
\text { tentukan }\end{array}$ & $\begin{array}{l}\text { Hasil perhitungan } \\
\text { sensor }\end{array}$ & \\
\hline 1. & $50 \mathrm{~cm}$ & $48 \mathrm{~cm}$ & Kosong \\
\hline 2. & $25-30 \mathrm{~cm}$ & $21-28 \mathrm{~cm}$ & Setengah \\
\hline 3. & $10 \mathrm{~cm}$ & $8 \mathrm{~cm}$ & Penuh \\
\hline
\end{tabular}

Pengujian ini dimulai untuk ketinggian tong sampah yaitu $50 \mathrm{~cm}$ sementara hasil perhitungan sensor yang terbaca $48 \mathrm{~cm}$. Jika perhitungan sensor berada di angka 50 . Pengujian pada level tengah jarak yang ditentukan adalah 25-30 cm sementara untuk hasil perhitungan sensor berada pada jarak 21-28 cm. Pengujian untuk level penuh ketinggiannya yang diatur adalah $10 \mathrm{~cm}$ sementara hasil 
perhitungan sensor untuk deteksi sensor adalah $8 \mathrm{~cm}$ sudah berada di level penuh.

\section{Pengujian pengiriman data ke Web server}

Pengujian Web server ini seperti pada tabel 5 adalah untuk mengetahui jarak keluaran sensor apakah sama dengan yang di tampilkan oleh Web server.

Tabel 5. pengiriman data ke Web server

\begin{tabular}{|l|c|c|c|}
\hline \multirow{2}{*}{ No } & \multicolumn{2}{|c|}{ Pengujian sensor pendeteksi level sampah } & \multirow{2}{*}{ Keterangan } \\
\cline { 2 - 3 } & $\begin{array}{c}\text { Hasil perhitungan } \\
\text { sensor }\end{array}$ & $\begin{array}{c}\text { Hasil tampilan Web } \\
\text { server }\end{array}$ & Sesuai \\
\hline 1. & $9 \mathrm{~cm}$ & $9 \mathrm{~cm}$ & Sesuai \\
\hline 2. & $14 \mathrm{~cm}$ & $14 \mathrm{~cm}$ & Sesuai \\
\hline 3. & $49 \mathrm{~cm}$ & $49 \mathrm{~cm}$ & \\
\hline
\end{tabular}

Penjelasan dari pengujian ini yaitu, input dari data Web server adalah hasil dari perhitungan sensor level sampah. Atau dapat di katakan data keluar dari perhitungan sensor harus sama dengan yang di tampilkan oleh bagan seperti pada Gambar 9.

\section{J. Pembahasan}

Berdasarkan hasil penelitian maka pembahasannya adalah pengujian sensor untuk mendetesi buka tutup tong sampah jarak yang ditentukan adalah $60 \mathrm{~cm}$, hal ini dibuktikan dengan pengujian sensor untuk membuka tutup tong sampah untuk membuka tong sampah sensor akan mendeteksi dari sampai $60 \mathrm{~cm}$ sementara lebih dari $60 \mathrm{~cm}$ sensor tidak memberikan instruksi untuk membuka tong sampah. Pengujian sensor pendeteksi level sampah dari hasil pengujian dikategorikan untuk levelnya adalah kosong, setengah dan penuh. Level kosong sensor mendeteksi pada jarak $48 \mathrm{~cm}$, level setengah sensor mendeteksi 21-28 cm sedangkan untuk level penuh sensor mendeteksi $8 \mathrm{~cm}$, dan untuk pengujian hasil tampilan Web server sudah sesuai dengan hasil perhitungan sensor.

\section{KESIMPULAN}

Simpulan dari artikel ini adalah Sistem tempat sampah pintar menggunakan raspberry pi dan internet of things (iot) dengan sistem teknologi informasi, yang mengirim informasi data ke Web server dan diolah di aplikasi thingspeak yang dapat di privat atau bisa di publik, sehingga dapat mengidentifikasi persoalan sampah yang berserakan. Penyatuan sistem dengan teknologi informasi, dapat memungkinkan tempat sampah bisa di monitoring dari jarak jauh. Dengan adanya otomatis motor penggerak pintu tong sampah, dapat memudahkan masyarakat membuang sampah.

\section{REFFERENSI}

[1] M. R. Pakaya, O. Musa, J. Karim, and S. Abdussamad, "SIG Lokasi UMKM Berbasis Android," Jambura J. Electr. Electron. Eng., vol. 2, no. 2, pp. 52-59, Jul. 2020.

[2] Z. Purnomo, J. Karim, B. Senung, and S. Abdussamad,
"Sistem Informasi Jasa Pemesanan Percetakan Berbasis Android," Jambura J. Electr. Electron. Eng., vol. 2, no. 2, pp. 44-51, Jul. 2020.

[3] A. W. A. Antu, S. Abdussamad, and I. Z. Nasibu, "Rancang Bangun Running Text pada Dot Matrix 16X160 Berbasis Arduino Uno Dengan Update Data System Menggunakan Perangkat Android Via Bluetooth," Jambura J. Electr. Electron. Eng., vol. 2, no. 1, pp. 8-13, Jan. 2020.

[4] Faisal, "aplikasi smart trash can dalam mengatasi persoalan sampah secara mobile berbasis android. instek, 2.," INSTEK, vol. 2, 2017.

[5] A. Wuryanto, N. Hidayatun, M. Rosmiat, and Y. Maysaroh, "Perancangan Sistem Tempat Sampah Pintar Dengan Sensor HCRSF04 Berbasis Arduino UNO R3," Paradig. - J. Komput. dan Inform., vol. XXI, no. 1, pp. 1-8, 2019.

[6] A. A.Md., A. Nugroho, S.T., MT., and U. Ali Ahmad, S.T., M.T., "Perancangan dan Implementasi Sistem Monitoring Untuk Pelaporan Sampah Berabasis Teknologi Embedded," J. e-Proceeding Eng., vol. 3, no. 1, pp. 666-673, 2016.

[7] Sukarjadi, D. T. Setiawan, Arifiyanto, and M. Hatta, "Perancangan Dan Pembuatan Smart Trash Bin Berbasis Arduino Uno Di Universitas Maarif Hasyim Latif," Tek. Eng. Sains J., vol. 1, no. 2, pp. 101-110, 2017.

[8] S. Abdussamad, "Rancang Bangun Inverter Mini 1.5 Vdc to 220 Vac Untuk Lampu Darurat," J. Tek., vol. 18, no. 1, pp. 7-16, Jun. 2020.

[9] M. R. Wirajaya, S. Abdussamad, and I. Z. Nasibu, "Rancang Bangun Mesin Penetas Telur Otomatis Menggunakan Mikrokontroler Arduino Uno," Jambura J. Electr. Electron. Eng., vol. 2, no. 1, pp. 24-29, Feb. 2020.

[10] W. Ridwan, I. Z. Nasibu, R. D. R. Dako, and I. Wiranto, "Sistem Pemantauan Dan Pengendalian Penerangan Rumah Berbasis Web Menggunakan Raspberry Pi," Semin. Nas. Tek. Elektro, vol. 1, no. 1, p. 225, 2017.

[11] S. Adriansyah Hulukati, T. Pratiwi Handayani, R. Jaya, and S. Abdussamad, "A prototype of solar-powered automatic ablution tap," IOP Conf. Ser. Mater. Sci. Eng., vol. 486, no. 1, 2019. 